\title{
Pentingnya Desain Ulang Pekerjaan Dan Deskripsi Pekerjaan Untuk Peningkatan Kinerja Pegawai Pada Masa Pandemi Covid 19
}

(Studi Kasus pada Pegawai Dinas Pekerjaan Umum dan Penataan Ruang Kabupaten Serang)

\author{
Nafiudin \\ Andari \\ Denny Kurnia \\ Andini Tia Safitri
}

Fakultas Ekonomi dan Bisnis, Program Studi Manajemen

Universitas Serang Raya

nafiuddin08@gmail.com

andinitia62@gmail.com

\begin{abstract}
This study is to examine the effect of Job Redesign and Job Description on Employee Performance in the Public Works and Spatial Planning Office of Serang Regency. The method used is a quantitative method. The population is 55 employees and the sample is 35 employees. Data were collected using a questionnaire. To test the model and hypothesis, the SPSS version 25 program was used. Based on the results of this study indicate: Job Redesign partially has no effect on employee performance. Job description partially positive and significant effect on employee performance. Job redesign and job description simultaneously have a positive and significant effect on employee performance.
\end{abstract}

\section{Keywords: Job Redesign, Job Description, Employee Performance}

\begin{abstract}
ABSTRAK
Penelitian ini Untuk menguji pengaruh Desain Ulang Pekerjaan dan Deskripsi Pekerjaan terhadap Kinerja Pegawai di Dinas Pekerjaan Umum dan Penataan Ruang Kabupaten Serang. Metode yang digunakan adalah metode kuantitatif. Populasi sebanyak 55 pegawai dan sampel sebanyak 35 pegawai. Data dikumpulkan dengan menggunakan kuesioner. Untuk menguji model dan hipotesis, digunakan program spss versi 25. Berdasarkan hasil penelitian ini menunjukkan: Desain Ulang Pekerjaan secara parsial tidak berpengaruh terhadap Kinerja Pegawai. Deskripsi Pekerjaan secara parsial berpengaruh positif dan signifikan terhadap Kinerja Pegawai. Desain Ulang Pekerjaan dan Deskrpi Pekerjaan secara simultan berpengaruh positif dan signifikan terhadap Kinerja Pegawai.
\end{abstract}

Kata kunci: Desain Ulang Pekerjaan, Deskripsi Pekerjaan, Kinerja Pegawai 


\section{PENDAHULUAN}

Sumber daya manusia merupakan salah satu faktor yang memegang peranan penting dalam setiap organisasi. Dalam menjalankan aktivitas sumber daya manusia, pegawai merupakan faktor penting untuk mencapai tujuan organisasi yang telah ditetapkan. Artinya dalam mencapai tujuannya, organisasi harus memberikan perhatian khusus kepada pegawai yang direkrut untuk mendukung perkembangan organisasi. Pada tahun 2020 merupakan tahun terjadinya pandemic covid 19, demi pencegahan penularan virus tersebut diberlakukan Pembatasan Sosial Berskala Besar di Wilayah Banten dengan kebijakan ini maka aktivitas perkantoran dibatasi sehingga Work Form Home adalah jalan keluar agar roda organisasi tetap berjalan dan kinerja organisasi tetap tercapai. Dan memiliki pegawai yang berkinerja baik dapat memudahkan pimpinan organisasi untuk mengarahkannya mencapai tujuan yang ingin dicapai, selain itu sumber daya manusia yang berkualitas diharapkan dapat mendorong tercapainya keunggulan organisasi. Kinerja pegawai pada Dinas Pekerjaan Umum dan Penataan Ruang Kabupaten Serang dapat diukur melalui data losstime dan data laporan fisik pada Dinas Pekerjaan Umum dan Penataan Ruang Kabupaten Serang. Pada data losstime tahun 2020 tingkat keterlambatan pegawai semakin meningkat sehingga kinerja tersebut perlu diperhatikan kembali karena banyaknya losstime yang terjadi akan berpengaruh terhadap kinerja pegawai tersebut. Dan pada data laporan fisik tahun 2020 dan tahun 2021 dapat disimpulkan bahwa pada tahun 2019 total target sebanyak 55,91\% dan realisasinya sebanyak 36,83\% sedangkan pada tahun 2020 total target sebanyak $57,41 \%$ dan realisasinya sebanyak $25 \%$, artinya target dari tahun 2019 dan tahun 2020 semakin meningkat, akan tetapi target/capaian tersebut dari tahun 2019 dan tahun 2020 semakin menurun. Bila dilihat dari tabel tersebut dapat disimpulkan bahwa kinerja pegawai tersebut semakin menurun sehingga kinerja pegawai tersebut perlu ditingkatkan kembali.

Dalam meningkatkan kualitas kinerja pegawai, departemen Sumber Daya Manusia (SDM) dapat melakukan strategi seperti desain ulang pekerjaan. Desain ulang pekerjaan dapat diartikan sebagai suatu bentuk perubahan pekerjaan yang meliputi tugas, kewajiban dan tanggung jawab dari suatu pekerjaan yang dimilikinya. tujuannya untuk mempermudah pekerjaan dan membuat pegawai tidak merasa bosan dengan pekerjaan yang telah mereka lakukan selama ini dan diharapkan dapat menginspirasi pegawai. Berdasarkan observasi pendahuluan yang dilakukan pada 30 orang responden di Dinas Pekerjaan Umum dan Penataan Ruang Kabupaten Serang pada variabel desain ulang pekerjaan adalah sebagai berikut: 


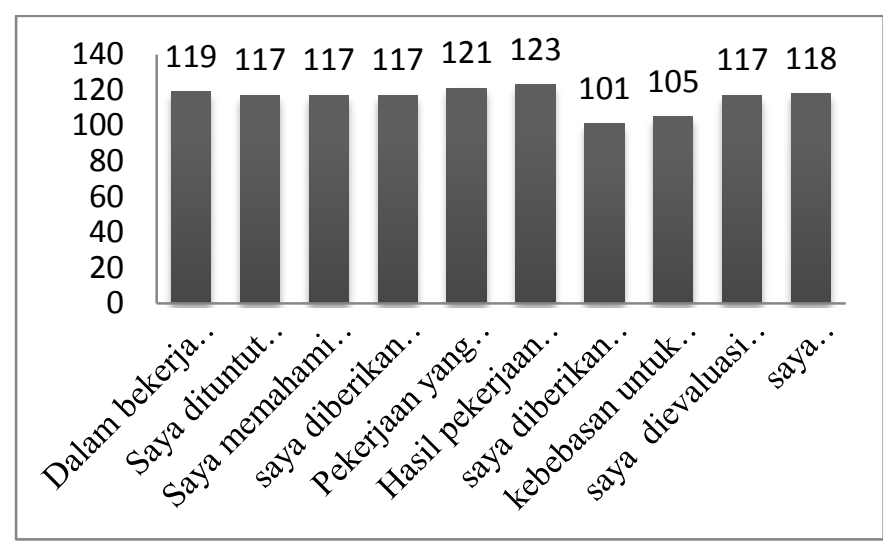

\section{Gambar Desain Ulang Pekerjaan di Dinas Pekerjaan Umum dan Penataan Ruang Kabupaten Serang}

Keterangan $\mathrm{n}=30$ Pegawai, skala 1s/d 5, skor tertinggi $(5 \times 30=150)$ dan skor terendah $(1 \times 30=30)$, sehingga standar skor $(150 / 2+30=105)$ Zikmund et al. (2010) dalam jurnal (Gentari et al. 2017:76).

Berdasarkan gambar di atas dapat disimpulkan bahwa desain ulang pekerjaan pada Dinas Pekerjaan Umum dan Penataan Ruang Kabupaten Serang terdapat nilai di bawah standar pada 1 indikator, yaitu indikator ketujuh dengan skor 101 yaitu adanya pegawai yang tidak diberikan kebebasan untuk memutus sendiri cara penyelesaian pekerjaan.

Deskripsi pekerjaan dalam suatu organisasi merupakan kumpulan informasi tentang apa saja kewajiban, dan tanggung jawab yang harus dilaksanakan oleh pegawai dalam suatu organisasi. Seorang pegawai harus mampu terhadap deskripsi pekerjaan yang telah diberikan kepadanya dengan penuh tanggung jawab dan melaksanakan tugasnya dengan baik dan benar. Selain itu, deskripsi pekerjaan dilakukan dalam rangka mencapai tujuan organisasi secara efektif dan efisien.

Berdasarkan observasi pendahuluan yang dilakukan pada 30 orang responden di Dinas Pekerjaan Umum dan Penataan Ruang Kabupaten Serang pada variabel deskripsi pekerjaan adalah sebagai berikut:

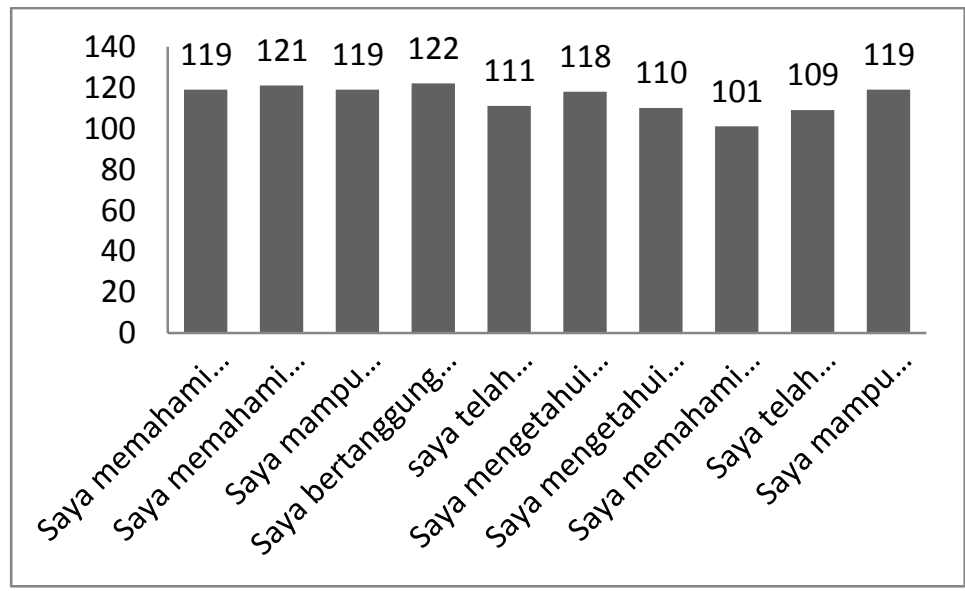




\section{Gambar Deskripsi Pekerjaan di Dinas \\ Pekerjaan Umum dan Penataan Ruang \\ Kabupaten Serang}

Keterangan $\mathrm{n}=30$ Pegawai, skala $1 \mathrm{~s} / \mathrm{d} 5$, skor tertinggi $(5 \times 30=150)$ dan skor terendah $(1$ x $30=30)$, sehingga standar skor $(150 / 2+30=105)$ Zikmund et al. $(2010)$ dalam jurnal (Gentari et al. 2017:76)

Berdasarkan gambar 1.2 di atas dapat disimpulkan bahwa deskripsi pekerjaan pada Dinas Pekerjaan Umum dan Penataan Ruang Kabupaten Serang terdapat nilai di bawah standar pada 1 indikator, yaitu indikator kedelapan dengan skor 101 yaitu adanya pegawai yang tidak memahami kondisi organisasi internal maupun eksternal.

Dari fenomena yang telah dijabarkan tersebut di atas, maka peneliti tertarik untuk rumusan malasah dalam penelitian ini adalah apakah terdapat Pengaruh Desain Ulang Pekerjaan Dan Deskripsi Pekerjaan Terhadap Kinerja Pegawai Pada Dinas Pekerjaan Umum Dan Penataan Ruang Kabupaten Serang”.

Adapun yang menjadi tujuan penelitiannya adalah menganalisis apakah Desain Ulang Pekerjaan Dan Deskripsi Pekerjaan memiliki pengaruh Terhadap Kinerja Pegawai Pada Dinas Pekerjaan Umum Dan Penataan Ruang Kabupaten Serang

\section{TINJAUAN PUSTAKA DAN PENGEMBANGAN HIPOTESIS}

\section{Desain Ulang Pekerjaan}

Menurut Albert (2002) dalam jurnal (Achieng et al. 2014:118) Desain ulang pekerjaan adalah penataan kembali unsur-unsur pekerjaan yang meliputi tugas-tugas dan tanggung jawab sebuah pekerjaan tertentu agar lebih memberi semangat dan inspirasi bagi pegawai. Menurut Hackman dan Oldman (2009) dalam jurnal (Pujoraharjo et al. 2015:510) berikut indikator yang digunakan adalah:

1. Variasi Keterampilan

2. Identitas Tugas

3. Signifikansi Tugas

4. Otonomi Tugas

5. Umpan Balik

\section{Deskripsi Pekerjaan}

Menurut Sastrohadiwiryo (2010) dalam jurnal (Elan \& Kurniawan, 2016:102) deskripsi pekerjaan adalah rincian pekerjaan yang berisi informasi menyeluruh tentang tugas/kewajiban, tanggung jawab, dan kondisi-kondisi yang diperlukan apabila pekerjaan tersebut dikerjakan. 
Menurut Dessler (2010) dalam jurnal (Wello \& Rauf, 2019:367) deskripsi pekerjaan adalah suatu daftar tugas, tanggung jawab, hubungan laporan, kondisi kerja, kepedulian atas tanggung jawab suatu jabatan, serta produk dari analisa jabatan.

Menurut Hasibuan (1995) dalam jurnal (Elan \& Kurniawan, 2016:102-103) indikator deskripsi pekerjaan yaitu;

1. Apa yang dilakukan

2. Tanggung Jawab

3. Kecakapan atau Pendidikan

4. Kondisi

5. Jenis dan Kualitas yang diperlukan

\section{Kinerja Pegawai}

Menurut Mathis dan Jaction (2001) dalam (Priansa, 2016:269) kinerja adalah apa yang dilakukan atau tidak dilakukan oleh pegawai dalam mengemban pekerjaannya.

Menurut Simanjuntak (2005) dalam jurnal (Syelviani, 2017:47) kinerja adalah tingkatan pencapaian hasil atas pelaksanaan tugas tertentu dalam rangka mewujudkan pencapaian hasil untuk mencapai tujuan.

Indikator kinerja menurut Bangun (2012) dalam jurnal (Putra et al., 2018:4):

1. Kualitas

2. Kuantitas

3. Ketepatan Waktu

4. Kehadiran

5. Kemampuan Bekerjasama

\section{Pengembangan Hipotesis}

$\mathrm{H}_{1}$ : Desain ulang pekerjaan berpengaruh signifikan terhadap Kinerja Pegawai

$\mathrm{H}_{2}$ : Deskripsi Pekerjaan berpengaruh signifikan terhadap Kinerja Pegawai

$\mathrm{H}_{3}$ : Desain Ulang Pekerjaan dan Deskripsi Pekerjaan berpengaruh signifikan terhadap

Kinerja Pegawai

\section{METODE PENELITIAN}

\section{Tempat penelitian}

Tempat dalam penelitian ini dilakukan di Kantor Dinas Pekerjaan Umum dan Penataan Ruang Kabupaten Serang yang terletak di Jalan Sama'un Bakri Serang.

\section{Populasi}

Populasi menurut Sugiyono (2017:80) adalah wilayah generalisasi yang terdiri atas: obyek/subyek yang mempunyai kualitas dan karakteristik tertentu yang ditetapkan oleh peneliti untuk dipelajari dan kemudian ditarik kesimpulannya. Populasi dalam penelitian ini 
adalah pegawai di Dinas Pekerjaan Umum dan Penataan Ruang Kabupaten Serang sebanyak 55 pegawai.

\section{Sampel}

Sampel menurut Sugiyono (2017:81) adalah bagian dari jumlah dan karakteristik yang dimiliki oleh populasi tersebut. Teknik sampling merupakan teknik pengambilan sampel. Untuk menentukan sampel yang akan digunakan dalam penelitian, terdapat berbagai teknik sampling yang digunakan.

Teknik yang di gunakan oleh peneliti adalah teknik Sampling Insidental. Menurut (Sugiyono, 2017:85) Sampling Insidental adalah teknik penentuan sampel berdasarkan kebetulan, yaitu siapa saja yang secara kebetulan/insidential bertemu dengan peneliti dapat digunakan sebagai sampel, bila dipandang orang yang kebetulan ditemui itu cocok sebagai sumber data. Jadi sampel penelitian ini adalah 35 responden yang terdiri dari Pegawai di Dinas Pekerjaan Umum dan Penataan Ruang Kabupaten Serang.

\section{Analisis Data \\ Uji Validitas}

Uji validitas sebagai salah satu syarat agar hasil penelitian dapat dikatakan ilmiah. Uji validitas ini untuk memastikan terlebih dahulu bahwa alat pengumpulan data harus diuji agar meyakinkan sebelum melakukan penelitian. Menurut Sudjana (2004) dalam (Tarjo, 2019:60) menyatakan bahwa validitas berkenaan dengan ketepatan alat penilaian terhadap konsep yang dinilai sehingga betul-betul menilai apa yang seharusnya dinilai. Suatu hasil uji yang dikatakan valid untuk tujuan tertentu atau pengambilan keputusan tertentu, mungkin tidak valid untuk tujuan atau pengambilan keputusan lain. Jadi suatu validitas, harus selalu dikaitkan dengan tujuan atau pengambilan keputusan tertentu.

\section{Uji Reliabilitas}

Menurut Sudjana (2004) dalam (Tarjo, 2019:73) menyatakan bahwa reliabilitas alat penilaian adalah ketepatan alat tersebut dalam menilai apa yang dinilainya. Artinya, kapanpun alat penilaian atau alat uji tersebut digunakan akan memberikan hasil yang relatif sama. Relatif sama dalam penelitian kuantitatif diartikan sebagai hasil uji yang menunjukkan bahwa nilai pengujiannya adalah dalam batas ruang yang telah ditetapkan sebelumnya.

\section{Uji Asumsi Klasik \\ Uji Normalitas}

Menurut Duli (2019:114-115) Uji normalitas bertujuan untuk melihat apakah nilai residual terdistribusi normal atau tidak. Model regresi yang baik adalah memiliki residual yang terdistribusi normal. Jadi uji normalitas bukan dilakukan pada masing-masing variabel tetapi pada nilai residualnya. Sering terjadi kesalahan yang jamak yaitu bahwa uji normalitas dilakukan pada masing-masing variabel. Hal ini tidak dilarang tetapi model regresi memerlukan normalitas pada nilai residualnya bukan pada masing-masing variabel penelitian.

\section{Uji Multikolonieritas}

Menurut Duli (2019:120) Uji multikolinieritas bertujuan untuk melihat ada atau tidaknya korelasi yang tinggi antara variabel-variabel bebas dalam suatu model regresi linear berganda. Jika ada korelasi yang tinggi di antara variabel-variabel bebasnya, maka hubungan antara variabel bebas terhadap variabel terikatnya menjadi terganggu.

\section{Uji Heteroskedastisitas}


Menurut Duli (2019:122) Uji heteroskedastisitas adalah untuk melihat apakah terdapat ketidaksamaan varians dari residual satu pengamatan ke pengamatan yang lain. Model regresi yang memenuhi persyaratan adalah di mana terdapat kesamaan varians dari residual satu pengamatan ke pengamatan yang lain tetap atau disebut homoskedastisitas. Deteksi heteroskedastisitas dapat dilakukan dengan metode scatter plot dengan memplotkan nilai ZPRED (nilai prediksi) dengan SRESID (nilai residualnya).

\section{Analisi Regresi Berganda}

Menurut Duli (2019:171-172) Analisis regresi linear berganda bermaksud mencari hubungan dari dua variabel atau lebih di mana variabel yang satu tergantung pada variabel yang lain. Secara umum, dapat dinyatakan pula bahwa apabila ingin mengetahui pengaruh satu variabel $\mathrm{X}$ terhadap satu variabel $\mathrm{Y}$ maka digunakan analisis regresi sederhana, dan apabila ingin mengetahui pengaruh dua variabel $\mathrm{X}$ atau lebih terhadap variabel $\mathrm{Y}$ digunakan analisis regresi ganda.

\section{Rancangan Uji Hipotesis}

\section{Uji- t}

Pengujian ini dilakukan untuk mengetahui signifikansi peran secara parsial antara variabel independen terhadap variabel dependen dengan mengasumsikan bahwa variabel independen lain dianggap konstan.

Menurut Sugiyono (2017) menggunakan rumus sebagai berikut:

$$
\mathrm{t}=\mathrm{r} \frac{\sqrt{n-2}}{\sqrt{1-r^{2}}}
$$

Keterangan :

$\begin{array}{ll}\mathrm{t} & : \text { Distribusi t } \\ \mathrm{R} & : \text { Koefisien korelasi parsial } \\ \mathrm{r}^{2} & \text { : Koefisien determinasi } \\ \mathrm{n} & \text { : Jumlah data }\end{array}$

\section{Uji -F}

Uji $\mathrm{F}$ adalah pengujian terhadap koefisien regresi secara simultan. Pengujian ini dilakukan untuk mengetahui pengaruh semua variabel independen yang terdapat di dalam model secara bersama-sama (simultan) terhadap variabel dependen. Uji F dalam penelitian ini digunakan untuk menguji signifikansi pengaruh Desain Ulang Pekerjaan dan Deskripsi Pekerjaan terhadap Kinerja Pegawai secara simultan dan parsial.

Menurut Sugiyono, (2017) dirumuskan sebagai berikut :

$$
F=\frac{R^{2 / K}}{\left(1-R^{2}\right) /(n-k-1)}
$$

Keterangan :

$\mathrm{R}^{2:}$ Koefisien Determinasi

$\mathrm{K} \quad$ : Jumlah variabel independen

$\mathrm{n} \quad$ : Jumlah anggota data atau kasus 
HASIL ANALISIS DAN PEMBAHASAN

Teknik Analisi Data

Uji Validitas

Uji Validitas Desain Ulang Pekerjaan

\begin{tabular}{|c|c|c|c|}
\hline Pernyataan & r hitung & r tabel 5\% & Hasil \\
\hline Pernyataan 1 & 0,377 & 0,333 & Valid \\
\hline Pernyataan 2 & 0,387 & 0,333 & Valid \\
\hline Pernyataan 3 & 0,784 & 0,333 & Valid \\
\hline Pernyataan 4 & 0,788 & 0,333 & Valid \\
\hline Pernyataan 5 & 0,769 & 0,333 & Valid \\
\hline Pernyataan 6 & 0,722 & 0,333 & Valid \\
\hline Pernyataan 7 & 0,684 & 0,333 & Valid \\
\hline Pernyataan 8 & 0,804 & 0,333 & Valid \\
\hline Pernyataan 9 & 0,831 & 0,333 & Valid \\
\hline Pernyataan 10 & 0,824 & 0,333 & Valid \\
\hline
\end{tabular}

Uji Validitas Deskripsi Pekerjaan

\begin{tabular}{|c|c|c|c|}
\hline Pernyataan & r hitung & r tabel 5\% & Hasil \\
\hline Pernyataan 1 & 0,856 & 0,333 & Valid \\
\hline Pernyataan 2 & 0,903 & 0,333 & Valid \\
\hline Pernyataan 3 & 0,867 & 0,333 & Valid \\
\hline Pernyataan 4 & 0,815 & 0,333 & Valid \\
\hline Pernyataan 5 & 0,837 & 0,333 & Valid \\
\hline Pernyataan 6 & 0,721 & 0,333 & Valid \\
\hline Pernyataan 7 & 0,883 & 0,333 & Valid \\
\hline Pernyataan 8 & 0,885 & 0,333 & Valid \\
\hline Pernyataan 9 & 0,863 & 0,333 & Valid \\
\hline Pernyataan 10 & 0,669 & 0,333 & Valid \\
\hline
\end{tabular}

\section{Uji Validitas Kinerja Pegawai}

\begin{tabular}{|c|c|c|c|}
\hline Pernyataan & r hitung & r tabel 5\% & Hasil \\
\hline Pernyataan 1 & 0,891 & 0,333 & Valid \\
\hline Pernyataan 2 & 0,838 & 0,333 & Valid \\
\hline Pernyataan 3 & 0,845 & 0,333 & Valid \\
\hline Pernyataan 4 & 0,865 & 0,333 & Valid \\
\hline Pernyataan 5 & 0,901 & 0,333 & Valid \\
\hline Pernyataan 6 & 0,940 & 0,333 & Valid \\
\hline Pernyataan 7 & 0,918 & 0,333 & Valid \\
\hline Pernyataan 8 & 0,850 & 0,333 & Valid \\
\hline Pernyataan 9 & 0,810 & 0,333 & Valid \\
\hline Pernyataan 10 & 0,884 & 0,333 & Valid \\
\hline
\end{tabular}




\section{Uji Reliabilitas}

\begin{tabular}{|c|c|c|c|}
\hline Variabel & $\begin{array}{c}\text { Nilai Cronbach's } \\
\text { Alpha }\end{array}$ & $\begin{array}{c}\text { Koefisien } \\
\text { Korelasi }\end{array}$ & Keterangan \\
\hline $\begin{array}{c}\text { Desain Ulang } \\
\text { Pekerjaan (X1) }\end{array}$ & 0,883 & 0,60 & Reliabel \\
\hline $\begin{array}{c}\text { Deskripsi } \\
\text { Pekerjaan (X2) }\end{array}$ & 0,948 & 0,60 & Reliabel \\
\hline $\begin{array}{c}\text { Kinerja Pegawai } \\
\text { (Y) }\end{array}$ & 0,962 & 0,60 & Reliabel \\
\hline
\end{tabular}

Berdasarkan hasil uji nilai cronbach's alpha $>$ koefisien korelasi 0,60 yaitu untuk variabel Desain Ulang Pekerjaan (X1) didapat nilai alpha sebesar 0,883 dan variabel Deskripsi Pekerjaan (X2) didapat nilai alpha sebesar 0,948 dan variabel Kinerja Pegawai (Y) sebesar 0,962. Dengan ini berarti seluruh variabel penelitian reliabel, karena nilai alpha dari setiap variabel lebih besar dari nilai $r$ tabel, sehingga dapat digunakan untuk bahan uji selanjutnya.

\section{Uji Asumsi Klasik}

\section{Uji Normalitas}

\begin{tabular}{|c|c|c|}
\hline \multicolumn{3}{|c|}{ One-Sample Kolmogorov-Smirnov Test } \\
\hline & & $\begin{array}{c}\text { Unstandardized } \\
\text { Residual }\end{array}$ \\
\hline \multicolumn{2}{|l|}{$\mathrm{N}$} & 35 \\
\hline \multirow[t]{2}{*}{ Normal Parameters ${ }^{a, b}$} & Mean &, 0000000 \\
\hline & Std. Deviation & ,62381585 \\
\hline \multirow[t]{3}{*}{ Most Extreme Differences } & Absolute &, 088 \\
\hline & Positive & ,057 \\
\hline & Negative &,- 088 \\
\hline \multicolumn{2}{|l|}{ Test Statistic } &, 088 \\
\hline \multicolumn{2}{|l|}{ Asymp. Sig. (2-tailed) } &, $200^{\mathrm{c}, \mathrm{d}}$ \\
\hline \multicolumn{3}{|l|}{ a. Test distribution is Normal. } \\
\hline \multicolumn{3}{|l|}{ b. Calculated from data. } \\
\hline \multicolumn{3}{|c|}{ c. Lilliefors Significance Correction. } \\
\hline
\end{tabular}

Berdasarkan tabel di atas tabel kolmogorov-smirnov menunjukkan bahwa signifikan sebesar 0,200 taraf signifikan yaitu > 0,05 maka dapat disimpulkan bahwa uji normalitas terpenuhi atau data brdistribusi normal.

\section{Uji Multikolinieritas}

Dari hasil uji multikolinieritas, diperoleh nilai tolerance untuk variabel Desain Ulang Pekerjaan dan Deskripsi Pekerjaan sebesar 0,438 > 0,10 bahwa tidak terjadi multikolinieritas dan dari nilai VIF untuk kedua variabel sebesar 2,282 < 10,00 maka dapat disimpulkan bahwa tidak terjadi multikolinieritas. 
Uji Heteroskedastisitas

\begin{tabular}{|c|c|c|}
\hline Variabel & Sig & Kesimpulan \\
\hline $\begin{array}{l}\text { Desain Ulang Pekerjaan } \\
\text { (X1) }\end{array}$ & 0,257 & $\begin{array}{c}\text { Tidak terjadi } \\
\text { heteroskedastisitas }\end{array}$ \\
\hline Deskripsi Pekerjaan (X2) & 0,353 & $\begin{array}{c}\text { Tidak terjadi } \\
\text { heteroskedastisitas }\end{array}$ \\
\hline
\end{tabular}

a.

Dependent Variable : Kinerja Pegawai

Dari hasil uji heteroskedastisitas tersebut, diperoleh nilai sig variabel Desain Ulang Pekerjaan sebesar 0,257 >0,05 dan Deskripsi Pekerjaan sebesar 0,353>0,05 maka dapat disimpulkan bahwa tidak terjadi heteroskedastisitas.

Uji Autokorelasi

\begin{tabular}{|c|c|c|c|c|c|}
\hline \multicolumn{6}{|c|}{ Model Summary } \\
\hline Model & $\mathrm{R}$ & R Square & $\begin{array}{c}\text { Adjusted R } \\
\text { Square } \\
\end{array}$ & $\begin{array}{c}\text { Std. Error of the } \\
\text { Estimate }\end{array}$ & Durbin-Watson \\
\hline 1 &, $947^{\mathrm{a}}$ & 897 & ,891 & 2,592 & 1,851 \\
\hline
\end{tabular}

Dari hasil perhitungan menggunakan SPSS diketahui bahwa nilai statistic DW sebesar 1,851. Sedangkan dalam tabel Durbin-Watson pada tingkat signifikan 5\% jumlah sampel 35 (n) akan didapat nilai batas atas (dU) sebesar 1,5838 dan batas bawah (dL) sebesar 1,3433.

Oleh karena itu, DW lebih besar dari batas atas (dU) yaitu sebesar 1,5838 dan pengurangan dari (4-dU) 4-1,5838 = 2,4162, maka dU < DW < 4-dU, sehingga 1,5838< $1,851<2,4162$ maka dapat disimpulkan bahwa tidak terdapat autokorelasi dalam model regresi dalam penelitian ini.

\section{Analisis Regresi Berganda}

\begin{tabular}{|c|c|c|c|c|c|c|}
\hline \multicolumn{7}{|c|}{ Coefficients $^{a}$} \\
\hline \multirow{2}{*}{\multicolumn{2}{|c|}{ Model }} & \multicolumn{2}{|c|}{$\begin{array}{c}\text { Unstandardized } \\
\text { Coefficients }\end{array}$} & \multirow{2}{*}{$\begin{array}{c}\text { Standardized } \\
\text { Coefficients }\end{array}$} & \multirow[b]{2}{*}{$\mathrm{t}$} & \multirow[b]{2}{*}{ Sig. } \\
\hline & & B & Std. Error & & & \\
\hline \multirow[t]{3}{*}{1} & (Constant) &,- 470 & 2,846 & &,- 165 &, 870 \\
\hline & Desain Ulang Pekerjaan & 167 & 110 & , 130 & 1,521 & 138 \\
\hline & Deskripsi Pekerjaan &, 829 &, 084 & ,845 & 9,861 & ,000 \\
\hline
\end{tabular}

Berdasarkan tabel di atas dapat dibentuk persamaan sebagai berikut:

$$
\begin{gathered}
Y=a+b_{1} X_{1}+b_{2} X_{2}+e \\
Y=-0,470+0,167+0,829+(-0,470)
\end{gathered}
$$

Keterangan :

$\mathrm{Y}=$ Kinerja Pegawai

$\mathrm{a}=$ konstanta 
$\mathrm{b}_{1} \mathrm{~b}_{2}=$ koefisien regresi

$\mathrm{X}_{1}=$ Desain Ulang Pekerjaan

$\mathrm{X}_{2}=$ Deskripsi Pekerjaan

$\mathrm{e}=$ Standar error

persamaan regresi di atas, dapat di interpretasikan bahwa :

- Nilai konstanta (a) adalah -0,470 ini dapat diartikan jika Desain Ulang Pekerjaan dan Deskripsi Pekerjaan nilainya adalah 1, maka Kinerja Pegawai nilainya -0,470.

- Nilai koefisien regresi variabel Desain Ulang Pekerjaan (b1) sebesar 0,167 menunjukkan koefisien regresi Desain Ulang Pekerjaan terhadap Kinerja Pegawai. Karena nilainya positif maka setiap kenaikan Desain Ulang Pekerjaan sebesr $1 \%$ maka Kinerja Pegawai akan mengalami kenaikan 0,167 \% jika variabel bebas lainnya dianggap tetap.

- Nilai koefisien regresi variabel Deskripsi Pekerjaan (b2) sebesar 0,829 menunjukkan koefisien regresi Deskripsi Pekerjaan terhadap Kinerja Pegawai. Karena nilainya positif maka setiap kenaikan Deskripsi Pekerjaan sebesar 1\% maka Kinerja Pegawai akan mengalami kenaikan sebesar 0,829\% jika variabel bebas lainnya di anggap tetap.

\section{Koefisien Determinasi}

\begin{tabular}{|l|c|r|r|c|}
\hline \multicolumn{7}{|c|}{ Model Summary } \\
\hline Model & $\mathrm{R}$ & R Square & $\begin{array}{c}\text { Adjusted R } \\
\text { Square }\end{array}$ & $\begin{array}{c}\text { Std. Error of the } \\
\text { Estimate }\end{array}$ \\
\hline 1 &, $947^{\mathrm{a}}$ &, 897 &, 891 & 2,592 \\
\hline \multicolumn{5}{|c|}{ a. Predictors: (Constant), Deskripsi Pekerjaan, Desain Ulang Pekerjaan } \\
\hline
\end{tabular}

Dari output model summary di atas, diketahui nilai R Square sebesar 0,897. Hal ini dapat diartikan bahwa variabel variabel Desain Ulang Pekerjaan dan Deskripsi Pekerjaan mempengaruhi sebesar $89,7 \%$ terhadap Kinerja Pegawai sedangka sisanya $10,3 \%$ di pengaruhi oleh faktor lain di luar variabel penelitian.

\section{Pengujian Hipotesis}

\section{Uji t}

\begin{tabular}{|c|c|c|c|c|c|c|}
\hline \multicolumn{7}{|c|}{ Coefficients $^{a}$} \\
\hline \multirow{2}{*}{\multicolumn{2}{|c|}{ Model }} & \multicolumn{2}{|c|}{$\begin{array}{c}\text { Unstandardized } \\
\text { Coefficients }\end{array}$} & \multirow{2}{*}{$\begin{array}{c}\text { Standardized } \\
\text { Coefficients } \\
\text { Beta }\end{array}$} & \multirow[b]{2}{*}{$\mathrm{T}$} & \multirow[b]{2}{*}{ Sig. } \\
\hline & & $\mathrm{B}$ & Std. Error & & & \\
\hline \multirow[t]{3}{*}{1} & (Constant) &,- 470 & 2,846 & &,- 165 & ,870 \\
\hline & Desain Ulang Pekerjaan &, 167 &, 110 &, 130 & 1,521 &, 138 \\
\hline & Deskripsi Pekerjaan & ,829 &, 084 & ,845 & 9,861 &, 000 \\
\hline
\end{tabular}


- Pengaruh Desain Ulang Pekerjaan terhadap Kinerja Pegawai berdasarkan uji statistik di atas, maka diperoleh hasil nilai $t_{\text {hitung }} 1,521$ untuk variabel Desain Ulang Pekerjaan sedangkan $\mathrm{t}_{\text {tabel }}$ pada tarafnya $\mathrm{a}=5 \%$ dengan distribusi khi kuadrat $(\mathrm{dK})=\mathrm{n}-\mathrm{k}-1=35$ 2-1= 32 maka didapat $t_{\text {tabel }}$ sebesar 1,694. Hasil tersebut menunjukkan bahwa $t_{\text {hitung }}<$ $\mathrm{t}_{\text {tabel }}(1,521<1,694)$ dan nilai sig 0,138>0,05 maka dapat disimpulkan bahwa $\mathrm{H}_{\mathrm{o}}$ diterima dan $\mathrm{H}_{\mathrm{a}}$ ditolak, yang artinya tidak terdapat pengaruh yang signifikan antara Desain Ulang Pekerjaan (X1) terhadap Kinerja Pegawai (Y).

- Pengaruh Deskripsi Pekerjaan terhadap Kinerja Pegawai berdasarkan uji statistik di atas, maka dapat diperoleh hasil nilai $t_{\text {hitung }} 9,861$ untuk variabel Deskripsi Pekerjaan sedangkan $\mathrm{t}_{\text {tabel }}$ pada taraf $\mathrm{a}=5 \%$ dengan distribusi khi-kuadrat $(\mathrm{dK})=\mathrm{n}-\mathrm{k}-1=35-2-1$ $=32$ maka di dapat $t_{\text {tabel }}$ sebesar 1,694. Hasil tersebut menunjukkan bahwa $t_{\text {hitung }}>$ $\mathrm{t}_{\text {tabel }}(9,861>1,694)$ dan nilai sig $0,000<0,05$ maka dapat disimpulkan bahwa $\mathrm{H}_{\mathrm{o}}$ ditolak $\mathrm{H}_{\mathrm{a}}$ diterima, yang artinya terdapat pengaruh yang signifikan antara Deskripsi Pekerjaan (X1) terhadap Kinerja Pegawai (Y).

\section{Uji F}

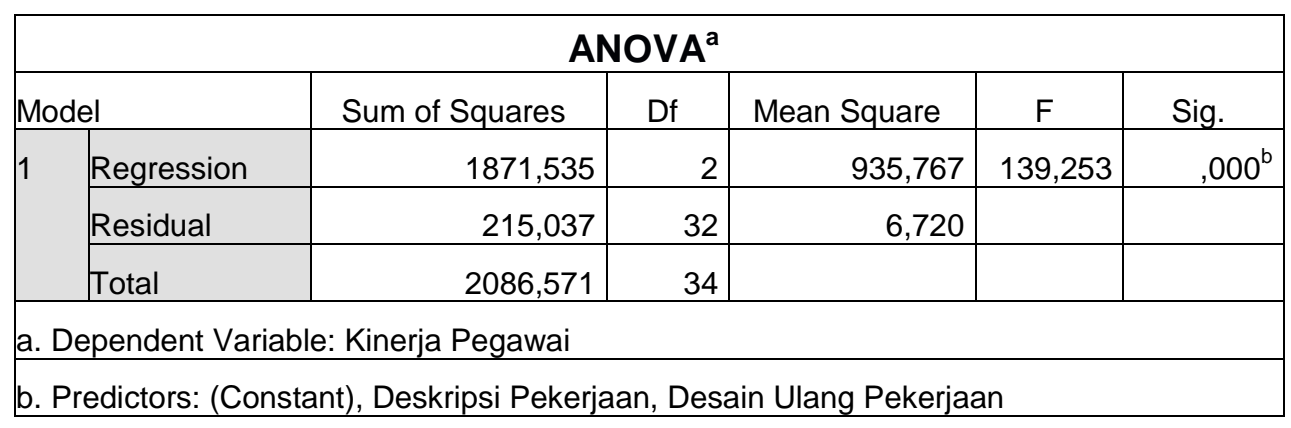

Setelah dilakukan uji $\mathrm{F}$, diperoleh $\mathrm{F}_{\text {hitung }}=139,253$ sedangkan nilai $\mathrm{F}_{\text {tabel }}(\mathrm{dF}=\mathrm{n}-\mathrm{k}-1$ $=35-2-1=32$ sebesar 3,29. Didapatkan hasil $F_{\text {hitung }}>F_{\text {tabel }}(139,253>3,29)$ dengan demikian $\mathrm{H}_{\mathrm{o}}$ ditolak dan $\mathrm{H}_{\mathrm{a}}$ diterima dengan tingkat signifikan sebesar $0,000(0,000<0,05)$. Dengan begitu dapat disimpulkan bahwa Desain Ulang Pekerjaan (X1) dan Deskripsi Pekerjaan (X2) secara simultan berpengaruh signfikan terhadap Kinerja Pegawai (Y) pada Dinas Pekerjaan Umum dan Penataan Ruang Kabupaten Serang.

\section{Simpulan}

Berdasarkan penelitian dan pembahasan yang dilakukan mengenai Desain Ulang Pekerjaan dan Deskripsi Pekerjaan terhadap Kinerja Pegawai pada Dinas Pekerjaan Umum dan Penataan Ruang Kabupaten Serang, maka di peroleh beberapa kesimpulan sebagai berikut:

1. Desain Ulang Pekerjaan tidak berpengaruh secara signifikan terhadap Kinerja Pegawai.

2. Deskripsi Pekerjaan berpengaruh secara signifikan terhadap Kinerja Pegawai.

3. Desain Ulang Pekerjaan dan Deskripsi Pekerjaan berpengaruh secara simultan terhadap Kinerja Pegawai.

\section{Saran}

Berdasarkan hasil pengkajian penelitian yang telah dilakukan, maka penulis bermaksud memberikan saran yang semoga dapat bermanfaat bagi organisasi terkait maupun bagi peneliti yang selanjutnya sebagai berikut: 
1. Bagi Organisasi Terkait

a. Desain Ulang Pekerjaan di Dinas Pekerjaan Umum dan penataan Ruang Kabupaten serang berdasarkan jawaban responden, untuk pernyataan no.item 7 "saya diberikan kebebasan untuk memutus sendiri cara penyelesaian pekerjaan" perlu ditingkatkan kembali, dengan cara memberi kebebasan kepada para pegawai dalam memutus cara penyelesaian pekerjaan.

b. Deskripsi Pekerjaan di Dinas Pekerjaan Umum dan Penataan Ruang Kabupaten Serang berdasarkan jawaban responden, untuk penrnyataan no.item 8 "saya memahami tentang kondisi organisasi internal maupun eksternal" perlu ditingkatkan kembali, dengan cara pegawai diberi pemahaman dalam mengenal tentang kondisi organisasi.

c. Kinerja Pegawai di Dinas Pekerjaan Umum dan Pentaan Ruang Kabupaten Serang perlu ditingkatkan kembali pada kehadiran dalam masuk kerja, dengan cara datang ke tempat kerja lebih awal agar tidak terlambatan.

2. Bagi Peneliti Selanjutnya

Bagi pihak lain yang ingin melakukan penelitian dengan variabel-variabel yang sama yaitu Pengaruh Desain Ulang Pekerjaan dan Deskripsi Pekerjaan terhadap Kinerja Pegawai, dapat mewakili secara tepat variabel yang hendak diukur agar lebih baik sehingga penelitian ini mendapatkan hasil yang lebih akurat lagi.

a. Bagi pihak lain apabila melakukan penelitian dilakukan di lokasi yang sama diharapkan mengganti variabel yang telah diteliti tersebut, karena setiap organisasi mempunyai permasalahan yang akan menjadi bahan penelitian.

\section{DAFTAR PUSTAKA}

Achieng, Opiyo Evelyn, Isaac Ochieng, Department of Commerce, Laikipia University., Silas Owuor, and Department of Management Science, Maseno University. 2014. 'Effect of Job Redesign on Employee Performance in Commercial Banks in Kisumu, Kenya'. Greener Journal of Business and Management Studies 4(4):115-37. doi: 10.15580/GJBMS.2014.4.040714179.

Agustin, Triana. 2019. 'Analisis Pengaruh Gaya Kepemimpinan Dan Job Description Terhadap Kinerja Pegawai Pada Kantor Badan Kepegawaian Daerah (BKD) Kabupaten Kediri'. 11.

Diana, Yana. 2020. 'Pengaruh Job Description Terhadap Kinerja Karyawan Di Departemen Tata Hidang Pada Hotel Grand Ion Deleman Malaysia’. 12(2):17.

Duli, Nikolaus. 2019. Metode Penelitian. Yogyakarta: Deepublish (Grup Penerbitan CV Budi Utama).

Elan, Umi, and Indra Kurniawan. 2016. 'Pengaruh Job Description Terhadap Kinerja Karyawan Departemen Security PT. Wilmar Nabati Indonesia Gresik’. 05:7.

Gentari, Rt Erlina, Sumiati, and St Handayani Aletya. 2017. 'Analisa Pengaruh Tingkat Absensi Dan Lingkungan Kerja Terhadap Kinerja Pegawai Di Biro Umum Setda Provinsi Banten'. Jurnal Ekonomi, Volume 19 No1, Universitas Serang Raya.

kardi, Su, and Yuli adi. 2020. 'The Effect of Job Description, Motivation, And Competence

On The Employee Performance of Semarang Secretary Office'. International Journal 
of Economics and Management Studies 7(11):46-49. doi: 10.14445/23939125/IJEMS-V7I11P107.

Mangkunegara, Anwar Prabu. 2017. Evaluasi Kinerja SDM. Bandung: PT Refika Aditama.

Priansa, Donni Juni. 2016. Perencanan Dan Pengembangan Sumber Daya Manusia. Bandung: Alfabeta.

Pujoraharjo, Purwandito, Zunaidah, and M. Diah Yuliansyah. 2015. 'Pengaruh Kompetensi Dan Desain Kerja Terhadap Kinerja Karyawan (Studi Kasus Di Departemen Gigi

Dan Mulut RSUP Dr. Mohammad Hoesin Palembang)'. 18.

Putra, Udin, Bakri Hasanuddin, and Wiri Wirastuti. 2018. 'Pengaruh Motivasi Kerja Dan Kompensasi Terhadap Kinerja Karyawan Pada PT. Balindo Manunggal Bersama Kota Palu'. On Line 4(1):10.

Siagian, P. Sondang. 2015. Manajemen Sumber Daya Manusia. Jakarta: Bumi Aksara.

Siengthai, Sununta, and Patarakhuan Pila-Ngarm. 2016. 'The Interaction Effect of Job Redesign and Job Satisfaction on Employee Performance'. Evidence-Based HRM: A Global Forum for Empirical Scholarship 4(2):162-80. doi: 10.1108/EBHRM-012015-0001.

Sugiyono. 2017. Metode Penelitian Kuantitatif, Kualitatif, Dan R\&D. Bandung: Alfabeta.

Syelviani, Meilisa. 2017. 'Pengaruh Deskripsi Pekerjaan terhadap Kinerja Pegawai Negeri Sipil pada Kantor Camat Tembilahan'. Journal of Economic, Bussines and Accounting (COSTING) 1(1):43-55. doi: 10.31539/costing.v1i1.48.

Tarigan, Calista Feby, Sufika Sari, and Florencia Magdalena Sitompul. 2019. 'Pengaruh Disiplin Kerja Dan Job Description Terhadap Kinerja Karyawan Pada PT.Giovani Abadi Sentosa'. 8:9.

Tarjo. 2019. Metode Penelitian. Yogyakarta: Deepublish (Grup Penerbitan CV Budi Utama).

Wello, Surya Kelana Basri, and Rusdiaman Rauf. 2019. 'Pengaruh Job Description Terhadap Kinerja Karyawan Pada PT. Sinar Lima Samudra'. 4:11. 